\title{
Universiteit
}

Leiden

The Netherlands

\section{Escaping the Reformation in the Republic of Letters: Confessional Silence in Latin Emblem Books \\ Visser, A.S.Q.}

\section{Citation}

Visser, A. S. Q. (2008). Escaping the Reformation in the Republic of Letters: Confessional Silence in Latin Emblem Books. Church History And Religious Culture, 88, 139-167. Retrieved from

https://hdl.handle.net/1887/13936

Version:

License:

Downloaded from: $\quad$ https://hdl.handle.net/1887/13936
Not Applicable (or Unknown)

Leiden University Non-exclusive license

Note: To cite this publication please use the final published version (if applicable). 


\title{
Escaping the Reformation in the Republic of Letters: Confessional Silence in Latin Emblem Books
}

\author{
Arnoud Visser
}

\begin{abstract}
Recent scholarship has advanced paradoxical conclusions about the relationship between Renaissance humanism and the Reformation. While humanist techniques are considered to have played an instrumental role in the development, spread, and implementation of the Reformation, the humanist community is generally regarded as a supra-confessional "Republic of Letters." This article addresses this paradox by looking at the religious language in Latin emblem books. These highly popular works emphasized a personal, intellectual spirituality, and expressed reservations against institutionalised religion. They have often been interpreted ideologically, as a humanistic, irenical response to the religious turmoil. When read in the context of the authors' and readers' practical interests, however, they reveal a more pragmatic strategy. Rather than promoting religious ideals, they used an a-confessional language to accommodate religious pluriformity. Examples of the reception by individual readers, e.g., in alba amicorum, further exemplify how confessional silence served as a communicative strategy in the Republic of Letters.
\end{abstract}

\section{Keywords}

Renaissance humanism; Reformation; Confessionalization; Emblem books; Republic of Letters.

\section{Introduction}

In assessing the impact of the Reformation on the intellectual culture of Renaissance humanism two recent studies came to contrasting conclusions. Focusing on the theological debates in the first half of the sixteenth century Erika Rummel described it as the confessionalization of humanism, a process which was more or less completed by the middle of the century. According to her, this "marriage between religion and culture" ultimately "circumscribed the progress of humanism." Yet in a recent survey of the connections between 
confessionalization and literature, Ute Lotz-Heumann and Matthias Pohlig make the opposite point, arguing that much of the humanist literary production escaped confessional control. According to them, the Republic of Letters "maintained a considerable degree of autonomy vis-à-vis confessionalization."

Partly, the contrasting outcome can be explained by the selection of sources. Rummel is concerned with explicit reflection on the religious developments, believing that only "a documented engagement with Reformation issues" can properly illuminate the humanists' response. ${ }^{2}$ This approach privileges the evidence that (increasingly) speaks a clear confessional, or anti-confessional language. Lotz-Heumann and Pohlig, on the other hand, look for both explicit and implicit connections between literature and emerging confessional discipline, which results in a more variegated picture of religious culture. The diversity they discern agrees with a more general trend in Reformation research. Rather than positing a linear, top-down formation of confessional identities, recent studies of religious moderation and practices of toleration have documented the dynamic interaction between a variety of religious "voices," including those who kept confessionally silent. ${ }^{3}$ Still, method cannot completely account for the contrasting conclusions. Lotz-Heumann and Pohlig recognize this and discern an intriguing paradox: while the humanist community seems to escape

1) I am grateful to Harald Hendrix and Lorna Hutson for helpful comments, as well as to audiences at St Andrews and Louvain, where earlier versions of the argument were presented.

Erika Rummel, The Confessionalization of Humanism in Reformation Germany (Oxford, 2000), p. I5I; Ute Lotz-Heumann and Matthias Pohlig, 'Confessionalization and Literature in the Empire, I555-1700,' Central European History 40 (2007), 35-6I, there 6I.

2) Rummel, Confessionalization of Humanism (see above, n. I), p. 4.

3) Luc Racaut and Alec Ryrie, eds., Moderate Voices in the European Reformation (Aldershot, 2005); Alexandra Walsham, Charitable Hatred: Tolerance and Intolerance in England I500I700 (Manchester, 2006); Benjamin Kaplan, Divided by Faith: Religious Conflict and the Practice of Toleration in Early Modern Europe (Cambridge, Mass., 2007). For the traditional confessionalization model, see Wolfgang Reinhard, 'Konfession und Konfessionalisierung in Europa,' in Bekenntnis und Geschichte. Die Confessio Augustana im historischen Zusammenhang, ed. Reinhard (Munich, I98I), pp. 165-189; Heinz Schilling, 'Die Konfessionalisierung von Kirche, Staat und Gesellschaft - Profil, Leistung, Defizite, und Perspektiven eines geschichtwissenschaftlichen Paradigmas,' in Die katholische Konfessionalisierung, ed. Wolfgang Reinhard and Heinz Schilling (Gütersloh, I995), pp. II-49; Thomas A. Brady, Jr., 'Confessionalization - The Career of a Concept,' in Confessionalization in Europe I555-I700: Essays in Honor and Memory of Bodo Nischan, ed. John M. Headley, Hans J. Hillerbrand, and Anthony J. Papalas (Aldershot, 2004), pp. I-20. 
confessional control, humanism nevertheless played a crucial role in confessional education at the universities. ${ }^{4}$

This article seeks to cast new light on the paradoxical relationship between humanist culture and increasing confessional discipline by investigating the religious language in an important genre of functional literature: the humanist emblem book. Emblems or emblemata consist of a motto (inscriptio), epigram (subscriptio), and picture (pictura), which together moralize exempla from (mostly) the classics and natural history. They can address a wide variety of subjects and comment on any major interest or concern of the humanist community. This makes them a goldmine for any student of early modern intellectual mentalities. The historical value of the genre is further increased by its success: the books were one of the most popular forms of humanist literature. The first specimen, the Emblematum libellus of the legal scholar Andrea Alciato in 153I, spawned a vogue which had a considerable impact on literary and visual culture. Alciato's work alone ran into more than one hundred editions within a century (including vernacular translations). By the end of the sixteenth century approximately twenty different Latin emblems collections had been published for the elite, humanist market. These books were disseminated throughout Europe in thousands of copies. ${ }^{5}$

Moreover, emblems are an intriguing source since their authors frequently claimed to speak a secret language, which gave more immediate access to deeper truths. This has led modern historians to see the genre as an expression of a particular philosophical or spiritual attitude, an "emblematic mentality" or "emblematic world view."" In relation to the Reformation, this spiritual mindset has been regarded as a position that was diametrically opposed to the contemporary climate of theological hair-splitting, censorship, and religious violence. In response to this, humanists would use their learned imagery irenically to demonstrate God's omnipresence in nature and to expose the

4) Lotz-Heumann and Pohlig, 'Confessionalization and Literature' (see above, n. I), 5I, 55, 6I.

5) See the chronological list by Hilary Sayles and Mario Praz, Studies in Seventeenth-Century Imagery, vol. 2 (Rome, 1974).

6) Seminal is E.H. Gombrich, 'Icones Symbolicae. Philosophies of Symbolism and their Bearing on Art,' in idem, Symbolic Images: Studies in the Art of the Renaissance (London, 1972), pp. 123-195, esp. pp. 160-165, 190-191. William B. Ashworth. Jr., 'Natural History and the Emblematic World View,' in Reappraisals of the Scientific Revolution, ed. David C. Lindberg and Robert S. Westman (Cambridge, 1990), pp. 303-332; Daniel S. Russell, Emblematic Structures in French Culture (Toronto, 1995); Peter M. Daly and John Manning, eds., Aspects of Renaissance and Baroque Symbol Theory (New York, 1999). 
vanity of trying to understand the world by language alone. ${ }^{7}$ Others have read part of the genre from a confessional perspective, analysing the meaning behind the allusive language of "Protestant emblem books" or focusing on the production for pedagogical and devotional uses (e.g., by the Jesuits), which surged in the seventeenth century. ${ }^{8}$ Yet while the former, general, interpretation was never actually tested, the confessional perspective seems too focused to accommodate the humanist emblem production of the long sixteenth century. For in contrast to a few confessionally outspoken works, such as those by Georgette de Montenay, or Théodore de Bèze, most of these Latin works seldom reflect on the religious debates of the day. ${ }^{9}$

This article seeks to overcome these obstacles by shifting attention to the practical use of the emblem book. After establishing the main characteristics of the religious discourse in these works, it will tease out its respective meanings in the specific contexts of individual authors, their immediate dedicatees and the eventual readership. Rather than providing evidence for alternative religious sympathies, I will argue, the emblems should be read as a-confessional gestures.

7) J.A. van Dorsten, The Radical Arts: First Decade of an Elizabethan Renaissance (Leiden, 1970), pp. 55-56; Ralph Dekoninck, 'Entre Réforme et Contre-Réforme: Les Imagines et figurae Bibliorum de Pieter van der Borcht et Hendrik Jansen van Barrefelt. Contribution à l'étude du statut et des fonctions de l'image dans les livres édités par Christophe Plantin et François Raphelengien,' Quaerendo 29 (1999), 96-125; Howard Louthan, The Quest for Compromise: Peacemakers in Counter-Reformation Vienna (Cambridge, 1997), pp. I40, I64; M.E.H.N. Mout, Bohemen en de Nederlanden in de zestiende eeuw (Leiden, 1975), pp. II6II7; Karel Porteman, Inleiding tot de Nederlandse Emblemataliteratuur (Groningen, 1977), pp. $85-86$.

8) For Protestant emblems, see Huston Diehl, 'Graven Images: Protestant Emblem Books in England,' Renaissance Quarterly 39 (1986), 49-64; Alison Adams, Webs of Allusion: French Protestant Emblem Books of the Sixteenth Century (Geneva, 2003). For the Jesuit production, mostly seventeenth-century, the literature is vast, see esp. G. Richard Dimler, Studies in the Jesuit Emblem (New York, 2007); Ralph Dekoninck, Ad Imaginem: Statuts, fonctions et usages de l'image dans le littérature spirituelle jésuite du XVIIe siècle (Geneva, 2005); J. Manning and M. van Vaeck, eds., The Jesuits and the Emblem Tradition (Turnhout, 1999). For Lutheran devotional use, see Sabine Mödersheim, 'Domini Doctrina Coronat.' Die geistliche Emblematik Daniel Cramers (I568-1637) (Bern, 1994).

9) About French vernacular emblem books with a non-confessional character, see Alison Saunders, 'The Emblem as a Form of Religious Literature,' in The Sixteenth-Century French Religious Book, ed. Andrew Pettegree, Paul Nelles, and Philip Conner (Aldershot, 200I), pp. 38-67 and Julie Barr, 'I am the Light of the World: Light as a Motif in Protestant and French Emblems,' in Emblemata sacra: rhétorique et herméneutique du discours sacré dans la littérature en images, ed. Ralph Dekoninck and Agnès Guiderdoni-Bruslé (Turnhout, 2007), pp. 465-48I. 
As such, these books can help us better to understand a key challenge of the European Republic of Letters: how to speak about God and religion in the face of mounting confessional pressures. ${ }^{10}$

\section{Characteristics of the Religious Discourse}

Despite being produced in different times and locations, humanist emblem collections present a remarkably coherent religious message. Since this is expressed in a to modern eyes perhaps rather intimidating combination of Latin verse and classical imagery, the reader first has to translate and decode the moral language. A host of ancient and mythological figures, ranging from Actaeon to Alexander the Great, Daphne to Daedalus, and Ganymede to the Graces, are meant to exemplify virtues and vices in specific ways as explained by the authors in the poem. ${ }^{11}$ Yet once this hurdle is taken, two main characteristics emerge.

The first is an emphasis on a personal, intellectual, spirituality. A classical image to promote this concept is the mythological figure of Ganymede, the handsome shepherd abducted by Zeus to serve as his Olympian waiter. Alciato interprets Ganymede in his emblem 'In Deo laetandum' (One should rejoice

10) The concept of the 'Republic of Letters' is here used to denote the community of humanists as a social and cultural group; for a critical, more restrictive assessment of the concept, see Herbert Jaumann, 'Respublica litteraria / Republic of Letters. Concept and Perspectives of Research,' in The European Republic of Letters in the Age of Confessionalism, ed. Herbert Jaumann (Wiesbaden, 200I), pp. II-I9.

11) The invention of most Latin collections started at the desk of the poet, e.g., Alciato, Bocchi (I555), Sambucus (I564), Junius (I565), Taurellus (I595), and Schoonhovius (I618). Here the epigrams convey the author's ideas most directly, while the picturae (usually commissioned by the publisher and produced by designer and craftsmen) can be regarded as visual interpretations of the epigrams (rather than vice versa). For the vast literature about Alciato a solid starting-point is Bernard F. Scholz, 'The I53I Augsburg Edition of Alciatus' Emblemata: A Survey of Research,' Emblematica 5.2 (I991), 213-254; for a recent sharp analysis, see Elisabeth Klecker, 'Des signes muets aux emblèmes chanteurs: les Emblemata d'Alciat et l'emblématique,' Littérature I45 (2007), 23-52; for Bocchi: Anne Rolet, 'Achille Bocchi's Symbolicarum Quaestionum libri quinque,' in Karl A.E. Enenkel and Arnoud S.Q. Visser, eds., Mundus Emblematicus: Studies in Neo-Latin Emblem Books (Turnhout, 2003), pp. IOI-I30; for Sambucus: Arnoud Visser, Joannes Sambucus and the Learned Image: The Use of the Emblem in Late-Renaissance Humanism (Leiden, 2005), pp. 215-258; for Junius, see C.L. Heesakkers, 'Hadriani Iunii Emblemata,' in Enenkel and Visser, Mundus Emblematicus, pp. 33-69, esp. 42-43; Taurellus, Emblemata physico-ethica, 2nd ed. (Nuremberg: C. Lochner, I602), sig. a $7^{\text {ro }}-\mathrm{a} 8^{\text {ro }}$; for Schoonhovius, Emblemata, partim moralia, partim etiam civilia (Gouda: A. Burier, I618; repr. Hildesheim, 1975), sig. * $5^{\text {ro }}-5^{\text {vo }}$. 
in God [no. 4] Plate I) as an allegory of intellectual contemplation and mystical union with God. ${ }^{12}$ The accompanying pictura depicts Ganymede's abduction by the eagle of Jove, and adds a verbal clue: the Greek words ganusthai mèdesi ("to rejoice in divine plans") hint at the etymological connection between Ganymede and spiritual meditation. ${ }^{13}$

A few decades later, Achille Bocchi's Symbolicae quaestiones (Bologna, I555) similarly stresses the need for intellectual spirituality. Indeed Bocchi emulates his predecessor by introducing two emblems about Ganymede (symbols 76 and 77), similarly interpreting the story as an example of intellectual spirituality and mystical union. The individual nature of this religious experience becomes even more pronounced in combination with Bocchi's emphasis on the relevance of silence. His enigmatic emblem 'Silentio deum cole' (Honour God in silence [symbol 62], Plate 2), accompanied by the second motto 'Saepe loqui nocuit, numquam nocuit tacuisse' (Speaking often harms, but keeping silent never does), describes silence as a condition for spiritual elevation:

We dedicate temples to the Mind, to Virtue, and Faith. We see, however, that they lie in ourselves. Why did Tritonian Pallas have her seat on the Capitoline hill? This was the head of the city and the world. The mind is an ornament of man, an image of the divine mind, never accessible to any of the senses. He who wants to know it, first of all has to know himself and to consult the Egyptian Harpocrates. ${ }^{14}$

12) Peter M. Daly, Virginia W. Callahan, and Simon Cuttler, eds., Andreas Alciatus (Index Emblematicus), vol. I: The Latin Emblems Indexes and Lists (Toronto, 2nd ed. 1988), emblem 4 (later references to this edition; some translations slightly adapted).

13) The etymology goes back to Xenophon, Symposion 8.28-30; for the neo-Platonic interpretation of the Ganymede story, see Erwin Panofski, 'The Neoplatonic Movement and Michelangelo,' in Studies in Iconology: Humanistic Themes in the Art of the Renaissance (New York, 1939), pp. 213-216; for sexual readings, see James M. Saslow, Ganymede in the Renaissance: Homosexuality in Art and Society (New Haven, 1986), pp. 18-47, and Stephen Orgel, 'Ganymede Agonistes,' GLQ: A Journal of Gay and Lesbian Studies 10.3 (2004), 485-501, esp. 490-495.

14) Symbolicarum quaestionum, de universo genere, quas serio ludebat libri quinque (Bologna: Academia Bocchiana, I555); all references to this edition. The epigram is followed by another: "He who is able to withdraw his mind from the senses and to lead his thought away from habit, easily surpasses everybody else. For he lives through his mind and as a god, while he who lives through the body and the senses lives as a coarse animal. He who takes this maxim of Hermes Trismegistus to heart cannot be unhappy." See also Barbara Bowen, 'Mercury at the Crossroads in Renaissance Emblems,' Journal of the Warburg and Courtauld Institutes 48 (1985), 222-229, there 228-229; Elisabeth See Watson, Achille Bocchi and the Emblem Book as Symbolic Form (Cambridge, 1993), pp. I40-I43; Rolet, 'Achille Bocchi's Symbolicarum Quaestionum' (see above, n. II), pp. I27-I28. For another example, see 'Fert tacitus, vivit, 


\section{Andreæ Alciati}

Tolle moras, femper nocuit differreparatis. Cui affine illud Onidianum :

2. In rebus gerendis librandas effe cuinc. que vires, eæ namque celeritati pares, \&

Sed propera,nec te venturas differ in horas: 2 ui non eft hodie, cras minus aptus erit. Martial.

contrà celeritas viribus ęqualis effe debe:: a'iterum enim fine altero non multumpo teft afferre comnodi, imo damna plerun. Non bene difulerts, videas q poffe negari. que maxima, funeftumque exitium hinc Id vuum ex preceptis Socratis refertur à confequitur. Faceffant ergocoruinz ro.

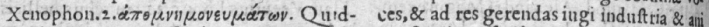
nuid agas, promptiffimè atque optime \& mi firmitate feriò accingamur. diligenter age.

\section{In Deo lętandum.}

\section{E M B L E M A I I I I.}

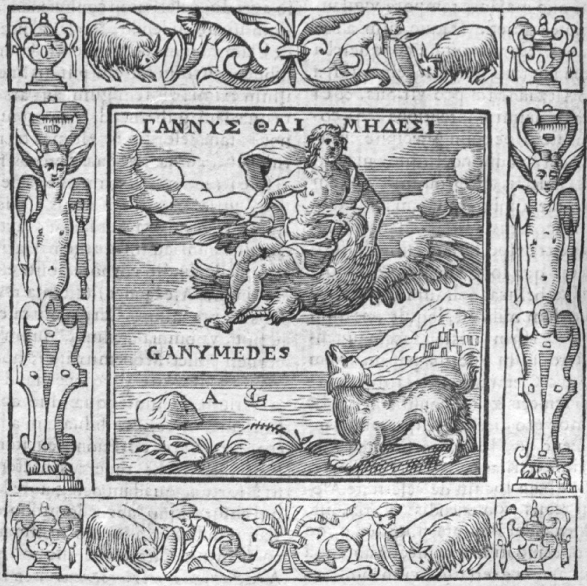

\section{A SPICE vt egregius puerum louis alite piztor Fecerit liacum fumma per aftra vehi. Quisne Iouem tactum puerili crédat amores? Dic, hac Mconius finxerit unde fenex? Conflium, mens atque Dei cui gaudia prestant, Creditur is fummo raptus adese Ioni.}

COM-

Plate I. The handsome shepherd Ganymede serves as an allegory of a personal, intellectual spirituality in Alciato's emblem 'In Deo laetandum' (One should rejoice in God). Photo of edition Padua: P.P. Tozzi, I6ı8, by Glasgow University Library.

vincit divinus amator' (The divine lover bears, sees, and conquers in silence [symbol I43]), adopting the neo-Platonic imagery of divine love. 


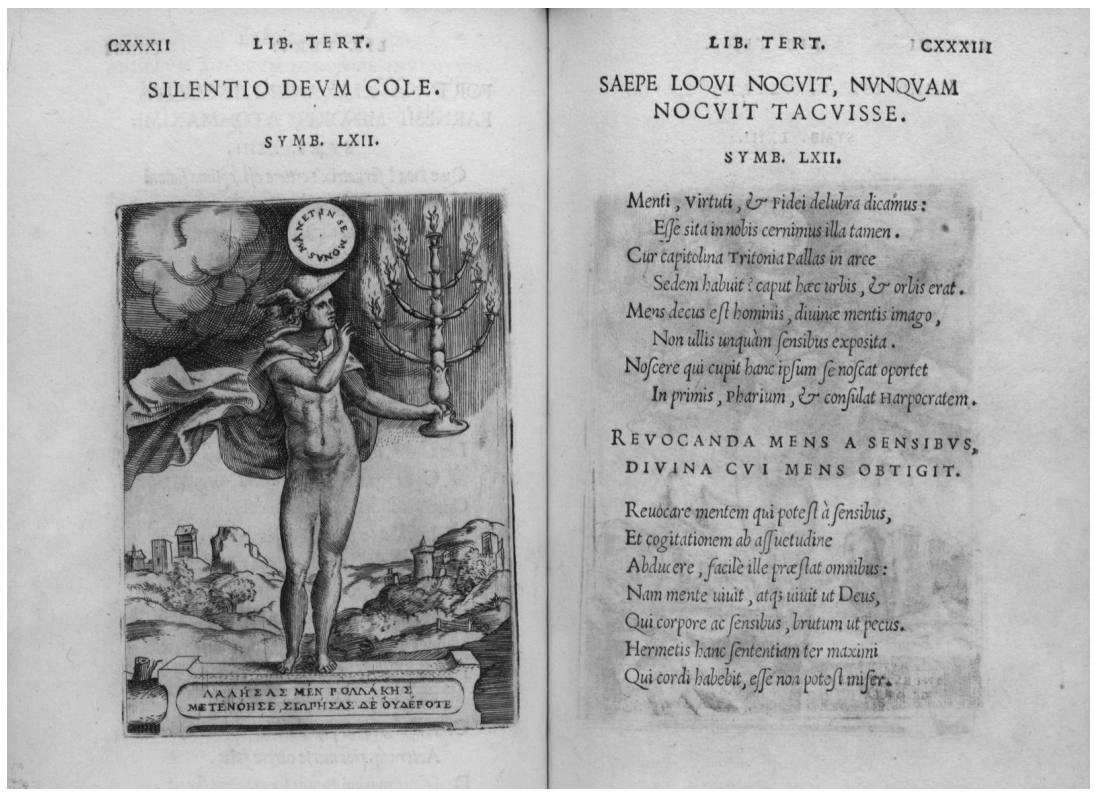

Plate 2. Bocchi emphasizes the role of silence as a condition for spiritual elevation in 'Silentio deum cole' (Honour God in silence). Photo: Glasgow University Library.

This intellectual spirituality is illustrated in the pictura by Hermes, traditionally the god of eloquence, but here a mystical guide, gesturing silence by putting his finger on his lips. In his other hand he holds a seven-branched candlestick, referring to the wisdom of the Jewish, cabbalistic tradition. In a circle of light the inscription "manet in se monas" (The One remains in itself) refers to the neo-Platonic ideal of mystical contemplation. Together, the allusive, syncretic language makes Bocchi's call for a private spirituality seem all the more detached from contemporary theological positions. ${ }^{15}$

Alciato and Bocchi wrote in the first half of the sixteenth century, at the dawn of the confessional age. Yet the stress on private spirituality persists in later collections, such as those of Joannes Sambucus and Hadrianus Junius, both published in the 1560 s by Christopher Plantin in Antwerp. ${ }^{16}$ Arguably

15) Classical allusions include Plutarch, De garrulitate 507a and 515a; Cicero, De natura deorum II.79; Corpus Hermeticum IV.5.

16) Sambucus, Emblemata et aliquot nummi antiqui operis (Antwerp: C. Plantin, 1566, 2nd ed.; repr. Hildesheim 2002), p. 72 ('Mens immota manet,' The mind stays unmoved); Junius, Emblemata (Antwerp: C. Plantin, I565; repr. Hildesheim, 1987), p. 33 ('Sermo de 


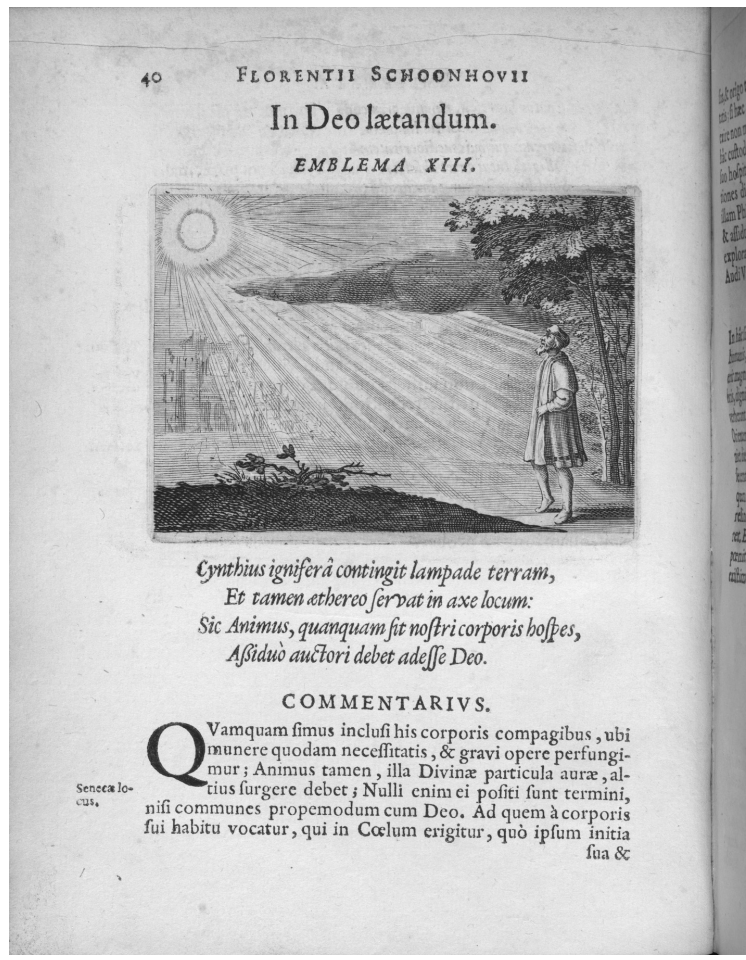

Plate 3. Schoonhovius combines the motto of Alciato's 'In Deo laetandum' with the image of light to call for personal spiritual elevation. Photo: Glasgow University Library.

the last examples can be found in the political emblems of the young lawyer Florentius Schoonhovius, published in the Calvinist setting of the Dutch Republic in 1618. ${ }^{17}$ In one example Schoonhovius borrows Alciato's motto 'In Deo laetandum' to call for spiritual contemplation, substituting the example of Ganymede with the metaphor of light (Plate 3). For although "a guest in

Deo apertus, mens sit occulta'; Let talk about God be public, but thought be private). All further references concern these editions.

17) See Karl Enenkel: 'A Leyden Emblem Book: Florentius Schoonhovius's Emblemata partim moralia, partim etiam civilia,' in The Emblem Tradition and the Low Countries, ed. J. Manning, K. Porteman, and M. van Vaeck (Turnhout, 1999), pp. 177-195; idem, 'Ein holländischer Horaz: Florentius Schoonhovius Poemata', ibid., pp. 197-225; and idem, 'Florentius Schoonhovius's Emblemata partim moralia, partim etiam civilia: Text and Paratext,' in Emblems of the Low Countries: A Book Historical Perspective, ed. Alison Adams and Marleen van der Weij (Glasgow, 2003), pp. I29-I47. 
our body," as Schoonhovius writes in a blend of neo-Platonic and neo-Stoic imagery, the mind, "that particle of divine breath, must rise higher." 18 Thus, almost a century after Alciato, humanist emblems still advocated a personal, intellectual, spirituality.

The second, related characteristic of the religious language in these emblem books is a critical attitude towards institutional forms of religion. Alciato's 'Ficta religio' (False religion [no. 6]), for example, uses the biblical image of the whore of Babylon (Rev. 17,3) to warn against pseudo-religion. Here "a very pretty whore, sitting on a throne" offers a drink to those surrounding her, causing a stupor wherever she goes: "Thus they indicate Babylon, who with her alluring beauty takes in the doltish nations with false religion." ${ }^{19}$ The image of Babylon evokes not only Augustine's frequent reference to the city of confusion and secular affairs, but also Luther's virulent critique of the traditional sacramental system in On the Babylonian Captivity of the Church (I520).

Other examples in Alciato are the emblems 'Non tibi, sed Religioni' (Not for you, but for Religion [no. 7]), criticizing religious ceremonies, and 'Sapientia humana, stultitia est apud Deum' (Human wisdom is foolishness before God [no. 5], Plate 4). The motto of the latter offers an interesting allusion. It paraphrases the biblical verse of Paul to the Corinthians (ICor. 3,19 ), concerning the internal quarrels of the Christian community, potentially a highly topical subject in the 1530 . This motto is coupled with an epigram about the legendary figure of King Cecrops, founder of Athens. He was supposed to be half man, half snake, which for Alciato comes to symbolize the presumptuous cleverness of a "man without religion." The emblem describes "human wisdom" as the product of a monstrously split nature, and characterizes interference in religious matters as blatant arrogance.

18) Emblem no. 13, pp. 40-4I: "The sun touches the earth with its burning light, but it also keeps its place in the sky above. In this way our Mind, although a guest in our body, must always be with God its Creator." In the commentary: "Quamquam simus inclusi his corporis compagibus, ubi munere quodam necessitatis, et gravi opere perfungimur; Animus tamen, illa Divinae particula aurae, altius surgere debet." Cf. Plato, Cratylus 40oC; Horace, Satires 2.2, 79 .

19) "Regali residens meretrix pulcherrima sella, / Purpureo insignem gestat honore peplum. / Omnibus et latices pleno e cratere propinat. / At circum cubitans ebria turba iacet. / Sic Babylona notant: quae gentes illice forma, / Et ficta stolidas religione capit.” 
Sapiétia humana, ftultitia eft apudDeú.

\section{E M B L E M A V.}

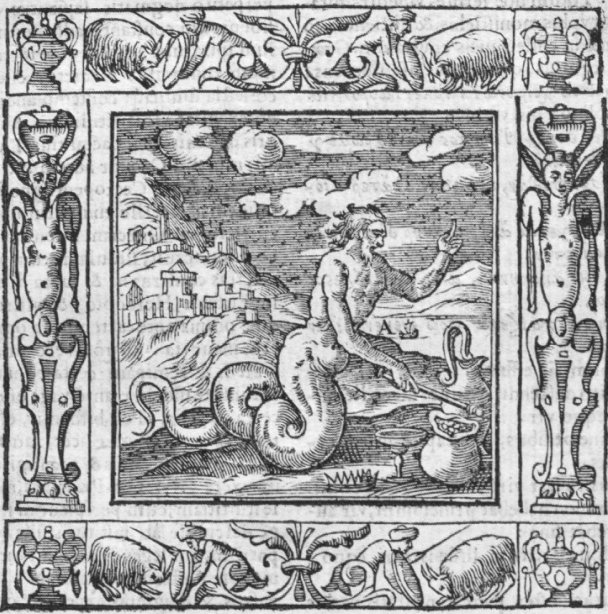

( V I D dicam? quonam boc compellem nomine monftrum Biforme, quod non est homo, nec est draco?

sed fine vir pedibus, fumm is fine partibus anguis, Vir anguipes dici, of homiceps anguis potest. Anguem pedit homo, hominem ersctauit or anguis:

Nec finis bominis eft, initium nec eft fere.

Sic olim Cecrops doct is regnanit Athenis:

Sic \& gigantes terra mater protulit.

Hac vafrum pecies, fed relligione carentem,

Terrena tantium quiǵ, curet, indicat.

\section{O M M E N T A R I I.}

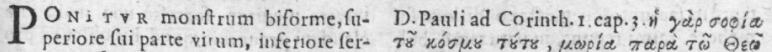
pentem referens, circa fcept ra, coronas, va ési. Sapien tia hutius mundi faltitia efo fa pretiofa, \& pecuniarum aceruos occu- apud Deum. Verfus funt Hexametri, \& patum. Infcriptio fum pra eft ex Epift. Trimetri Iambici.

C $\mathrm{HOC}$

Plate 4. Paraphrasing Paul's words to the Corinthians, Alciato's 'Sapientia

humana, stultitia est apud Deum' (Human wisdom is foolishness

before God), uses the mythological character of Cecrops to mock the cleverness of people "without religion." Photo: Glasgow University Library. 
Half a century later, similar criticism was made by Joannes Sambucus, who had personally witnessed the destruction of the French wars of religion. Some of his emblems respond directly to contemporary developments, but again the classics provide the imagery for his argument. For example, an emblem against iconoclasm, ('Sacra ne violato,' Do not profane what is sacred [244], Plate 5), proceeds from a story by the ancient geographer Pausanias about respect for offerings. Sambucus then applies the exemplum to the contemporary religious traditions:

The heavenly creatures are propitious and God hears one's prayers the moment one feels regret and shame. But when by chance you see an offering which once had the most sincere functions, made piously and with pure intentions, why should you want to violate it? Why eagerly molest and lay your sacrilegious hands on what is forbidden?

Sambucus clearly hints that certain rituals - the reference to regret and shame suggests confession and penitence in particular - may not be necessary, but criticizes aggressive attempts to stop such practices.

Another critical issue for Sambucus concerns religious leadership. In 'Principum negligentia' (Carelessness of princes [187]), he compares modern secular and spiritual leaders to the one-eyed mythological creature of the Cyclops, more precisely, Polephemus, the alcoholic shepherd blinded by Odysseus. The world is in a sorry state, Sambucus argues, when people must "ascend to Olympus" alone, since their leaders do not offer any guidance anymore. In this jungle of religious life, Sambucus suggests a moderate course of action: "I am just a simple man, who believes that hideous abuses should always be avoided, but I do not think that everything of the forefathers should be abolished." 20

Just like the theme of personal spirituality, the critical attitude towards authorities also continues into the seventeenth century. Schoonhovius, for example, openly attacks the theological debates in his days in 'Altum sapere periculosum' (It is dangerous to be highminded, [no. 3] cf. Rom. II, 2O, Plate 6). Here two notorious examples of hybris, Phaethon and Icarus, illustrate the dangerous consequences of inappropriate religious curiosity. Man should not

20) "Crassus ego tetros fugiendos semper abusus / Censeo, sed veterum cuncta levanda nego. / Quisque suo sensu regitur, conscendit Olympum, / Nec monstrant gressus qui voluere duces." 


\section{4 \\ I. $S A M B V C I$ \\ Sacra ne violato. Domino Paulo Bornemiffa Epifcopo Transyluamicnfi.}

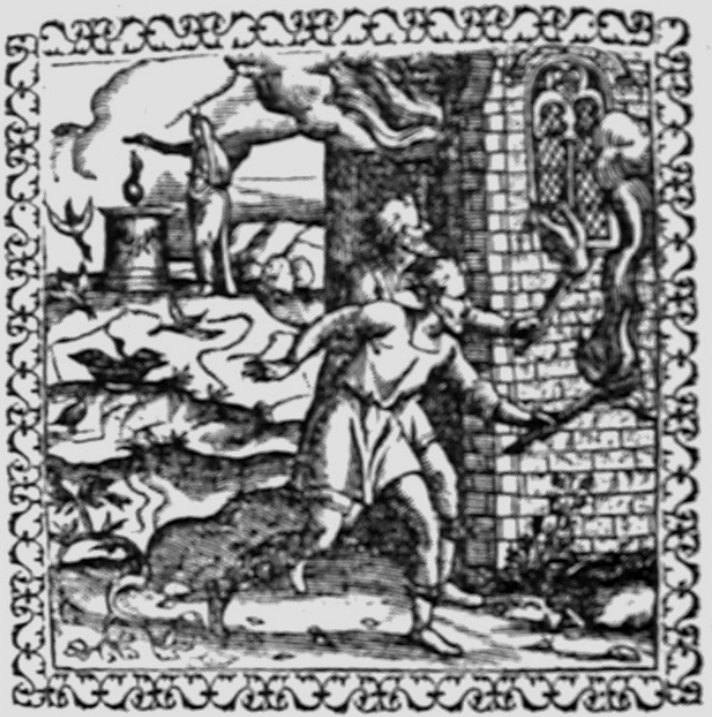

A R A M Paufanias in fummo dicit Olympo. C on pectam, circum quam facta pilia forent.

E xta etiam cerni volucres que int alta rapaces $L$ iquiffent, fuperím quod rata vota manent. $S$ unt faciles fuperi, precibus $\int e f e$ deus offert Hor a, qua erroris penitet, at que pudet. Forte tamen fi quid non vanis vfibus olims Et pura oblatum mente, piég $_{3}$ vides: C ur temerare velis, cupideg in peius abuti, $S$ acrilegas vetitis inijcere atque manus?

Plate 5. Sambucus applies an anecdote from the Greek geographer Pausanias to the contemporary issue of iconoclasm, in 'Sacra ne violato' (Do not profane what is sacred). Photo: private collection. 


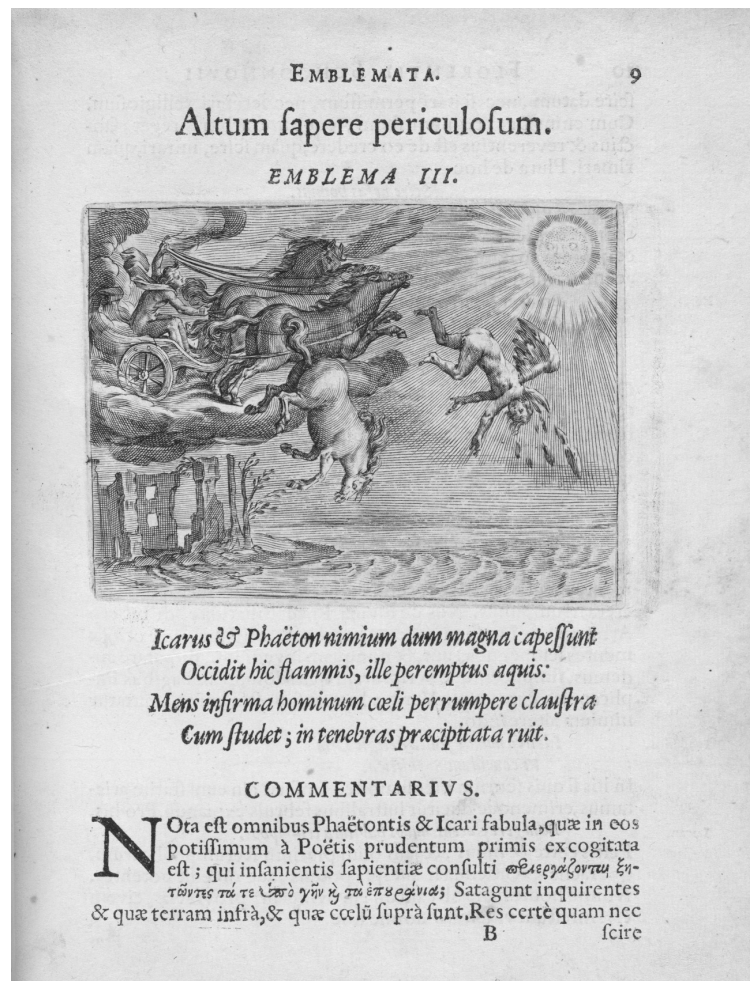

Plate 6. In 'Altum sapere periculosum' (It is dangerous to try to understand heaven) Schoonhovius uses two pivotal examples of human arrogance, Phaethon and Icarus, to criticize the theological debates of his time. Photo: Glasgow University Library.

use his "unstable mind to force its way through the gates of heaven."21 All these investigations of into predestination, free will, primal sin are idle and damaging: "people with too much time ... contaminate the pure Scripture in obscure examinations." He believes it is more appropriate "to have faith than to have knowledge, to worship than to analyze," not only because it is presumptuous to speculate about God, but also because it leads to social and political unrest. In his commentary Schoonhovius especially criticizes the role

21) Schoonhovius, Emblemata (see above, n. II), pp. 9-I2. For this theme and more emblematic examples, see Carlo Ginzburg, 'High and Low: The Theme of Forbidden Knowledge in the Sixteenth and Seventeenth Centuries,' Past and Present 73 (1976), 28-4I, esp. 38-4I; repr. in Myths, Emblems, Clues (London, 1990), pp. 60-76. 
of the militant ministers. They only "add fuel to the flames" while they should show "modesty and self-restraint." 22

What, then, do these characteristics imply? From a theological perspective, the examples seem to suggest spiritualist tendencies: Instead of supporting traditional, communal practices, the authors concentrated on the individual's access to God through spiritual contemplation, ignoring, or even criticizing institutional religion. Such notions were pervasive since the late Middle Ages, but gained a more topical significance as part of the so-called Radical Reformation, with proponents such as Sebastian Franck and Caspar von Schwenckfeld. Proceeding from this perspective, some scholars have linked the emblem collections published by Christopher Plantin to the spiritualist sect of the Family of Love. ${ }^{23}$

Moreover, with their indirect presentation of this message, they may be associated with Calvin's definition of the Nicodemite. ${ }^{24}$ For Calvin those who only secretly sympathized with the reformed position seriously undermined the struggle for true religion. In his Excuse à messieurs les nicodemites (I544) he therefore denounces the Nicodemite as a hypocrite, who divided his faith between God and the devil, "reserving his soul to the one and his body to the other." Calvin distinguished four main motives for this type of behaviour: financial gain, social indulgence, philosophical indifference, or practical anxiety. Of these he believed that philosophical indifference was the typical mistake of "almost all men of letters." While "taking into their heads

22) Schoonhovius, Emblemata (see above, n. II), pp. 9-I2.

23) Van Dorsten, The Radical Arts (see above, n. 7), pp. 55-56; Dekoninck, 'Entre Réforme et Contre-Réforme' (see above, n. 7), II3-II4; Porteman, Inleiding (see above, n. II), 85-86. See discussion by Visser, Joannes Sambucus (see above, n. II), pp. 58-62.

24) John Calvin, Excuse [...] à messieurs les nicodemites, ed. Francis M. Higman (London, 1970); modern historiography starts with Delio Cantimori, Eretici italiani del Cinquecento e Prospettive di storia ereticale italiana del Cinquecento (Florence, 1939; rev. repr. Turin, 2002); for nicodemism as a unified movement, see Carlo Ginzburg, Il nicodemismo: Simulazione e dissimulazione religiosa nell'Europa del 'Soo (Turin, I970); disputed and further diversified by Carlos M.N. Eire, 'Calvin and Nicodemism: A Reappraisal,' Sixteenth Century Journal Io (1979), 45-69; Perez Zagorin, Ways of Lying: Dissimulation, Persecution, and Conformity in Early Modern Europe. (Cambridge, Mass., 1990), pp. 63-99; Andrew Pettegree, 'Nicodemism and the English Reformation,' in Marian Protestantism: Six Studies, ed. Andrew Pettegree (Aldershot, I996), pp. 86-II7; M. Anne Overell, 'Vergerio's Anti-Nicodemite Propaganda and England, I547-1558,' Journal of Ecclesiastical History 5I (2000), 296-318; Mirjam van Veen, 'Verschoninge van de roomsche afgoderye': De polemiek van Calvijn met nicodemieten, in het bijzonder met Coornhert ('t Goy-Houten, 20oI); for the connections with humanism, see Rummel, Confessionalization of Humanism (see above, n. I), pp. IO2-I2O. 
Platonic ideas about how to serve God" they "justify most of the foolish superstitions of the Papacy." What is more, they acknowledge the right path in their study rooms, but avoid and even mock religious debates. ${ }^{25}$

So is the emblem book an exponent of a covert spiritualism? To test such a hypothesis we need to look beyond the emblems for evidence which can put these statements into perspective. The best opportunity to do so, is by looking at Alciato, whose varied production, and in particular his correspondence, offers a particularly rich test-case.

\section{Authors and Their Motives, I: Pragmatic Dissimulation}

As with so many humanists, Alciato's religious sympathies are intriguingly elusive. On the one hand, his reputation does not suggest he was considered a heterodox thinker. When his emblems were published in Augsburg, the author was known as a pedagogically gifted professor at Bourges, whose only reform programme concerned the study of Roman law. Erasmus had praised him in his Adages as "the ornament in this age, not only of civil law, but of all studies." 26 Later the Vatican would show its esteem for the scholar by making him a protonotary apostolic, a member of one of the highest colleges of prelates, and by asking his advice on the Council of Trent. ${ }^{27}$ On the other hand, however, in a range of sources he voices a striking variety of religious sentiments.

First, his most systematic religious work, the short treatise Contra vitam monasticam (Against the monastic life), takes a reformist position. This text, written around 1517 , is a vehement attack on monasticism in general, and on the Franciscan order in particular. It takes the form of a letter by Alciato, then still a lawyer in Milan, to his friend and colleague Bernardus Mattius, who had converted to the Franciscans shortly before. Alciato is shocked about his friend's choice. He criticizes the monastic life-style as socially and intellectually dry, but also suggests a programme for reform, inspired by the examples of the New Testament and the antique sect of the Essenes. He emphasized in particular the value of marriage over the celibate, and that of the active over

25) Calvin, Excuse (see above, n. 24), pp. 134, I39; see also Rummel, Confessionalization of Humanism (see above, n. I), p. I03.

26) Cited by Virginia Callahan, 'Erasmus' Adages. A Pervasive Element in the Emblems of Alciato,' Emblematica 9 (1995), 24I-256, there 242.

27) Roberto Abbondanza, 'Alciato (Alciati), Andrea,' in Dizionario biografico degli Italiani (Rome, 1960), pp. 69-77, there p. 73. 
the contemplative life. He furthermore stated that these existential decisions in life should be based on the free will of the individual. ${ }^{28}$

Such anti-clerical ideas were not particularly remarkable before the Reformation, but in the wake of Luther's rise quickly became much more sensitive. Alciato was acutely aware that his text would now be read in a different light, and therefore tried to suppress it. When the treatise ended up on Erasmus's desk, Alciato was apalled. "Free my letter from the claws of Erasmus," he wrote to his friend, the publisher Francesco Calvo, comparing the humanist giant to a mocking bird, "to prevent it from falling into the hands of the monks." 29 Warned by the example of the Dutch humanist, whom he saw "implicated in so many difficulties," he wanted nothing else than to stay away from "these hooded ones." Indeed, he panicked at the thought of what would happen if the treatise were published: "Luther, Pikarts, Hussites, and the other names of heretics will not be as notorious as my name will be." He would rather be "a national traitor, or the enemy of the mightiest king than have a conflict with the monks." More precisely, he feared "their force, their control, personal attacks in the pulpits, public imprecations, condemnations, and an ocean of trouble like this." 30 When Erasmus did not return the letter, Alciato wanted him to burn the work. In the end, Alciato succeeded in preventing publication during his lifetime, but the manuscript was never destroyed. More than a century later it was published in the Calvinist setting of Leiden. Shortly thereafter it was officially banned by the Catholic authorities. ${ }^{31}$

Against the background of this affair, the Emblemata could justifiably be read as the work of a Nicodemite who hid his Reformist sympathies behind classical imagery and allusions. Yet other evidence points in the opposite direction. In a commentary on a fragment of the Codex Justiniani, entitled De summa trinitate et fide catholica (first published Lyon I530), Alciato is not just orthodox in his views on the Church and the authority of the clergy, but extensively critical of

28) Karl A.E. Enenkel, 'Alciato's Ideas on the Religious: The Letter to Bernardus Mattius,' Emblematica 9 (1995) 293-313, esp. 303-313. A modern edition of the letter is in Le lettere di Andrea Alciato giureconsulto, ed. Gian Luigi Barni (Florence, 1953), pp. 265-290. All further references to Alciato's correspondence are to Barni; see also Roberto Abbondanza, 'A Proposito dell'epistolario dell'Alciato,' Annali di storia dell'diritto I (1957), 467-500.

29) Alciato to Calvo, 26 September 1520 , Barni no. 3, p. 8, 1. I4O.

30) Alciato to Calvo, Io December I520, Barni no. 4, pp. 9-IO; Alciato to Amerbach, 5 September I52I, Barni no. I5, p. 36, 11. 29-3I.

31) Leiden: F. Haaring, I695; banned by decree of the Congregation of the Index on 23 March I700, see Index Librorum Prohibitorum 1600-1966, ed. J.M. de Bujanda et al. (Montreal, 2002), p. 58, see also Enenkel, 'Alciato's Ideas on the Religious' (see above, n. 28), 302-303. 
the evangelical stance on the papacy. In considering some of the "preposterous" arguments against the primacy of the pope, he characterizes the evangelicals as quarrelsome people, who are "more tenacious than that tumor and hydra of Platonism," and only intent on "destroying unity."32

In several letters, he expresses an equal dislike for the Protestant reformers. When in I520 Luther burned works of canon law together with the papal bull Exsurge, domine which had condemned him as a heretic, Alciato characterizes this as an "absurd act of revenge." 33 In another letter, written to cheer up Erasmus who was depressed by the many controversies surrounding him, he regards criticism from Lutherans as a positive indication of moral righteousness. ${ }^{34}$ Most revealing, however, are the more intimate letters to Calvo. To the latter's repeated requests for an opinion on the case of Luther, Alciato reacted with irritation: "Why do you force this Lutheran business on me all the time? Personally I do not mind whether he is doing right or wrong and since it does not concern me, I cannot be bothered." 35

In fact, Alciato was above all consistent in his wish to avoid possible conflicts. He not only tried to suppress the publication of his critique of monasticism, but later also his statements in De summa trinitate for fear of Protestant reactions. ${ }^{36}$ His attempt to prevent conflicts was motivated by a desire to protect his honour, as well as his economic interests: "Most people here are jealous of me, because I earn one thousand royal écus with my professorship in law, whereas they have no position themselves, so that they stand prepared at every opportunity that may come to stain their affairs as well as me with malice." ${ }^{37}$

Altogether, then, Alciato's attitude shows to what extent concerns about career and reputation guided his behaviour. It also reveals how the opinions he expressed have to be understood in a rhetorical context. In the case of his letter against monasticism, Alciato could thus write the opposite of what he argued in his commentary on the Codex Justiniani. It is only thanks to some candid letters that we can put these contrasting views into perspective.

\footnotetext{
32) Alciato, Opera omnia, vol. 3 (Basel: M. Isengrin, I558), cols. 192-195.

33) Alciato to Calvo, 5 February I52I, Barni no. 8, p. 24, 11. I3-I9.

34) Alciato to Erasmus, 29 May I522, Barni no. 22, pp. 43-44 (= Allen no. I288, 11. I7-I9).

35) Alciato to Calvo, 24 April I52I, Barni no. Io, p. 28, 11. 44-48. See also Alciato to Calvo, 5 April I52I, Barni no. 9, 26, 11. I-5.

36) Alciato to Amerbach, 7 May I529, Barni no. 5I, pp. 92-93, ll. I34-I40; II June I529, Barni no. 53, p. 94, 11. I7-2I.

37) Alciato to Amerbach, 8 February I53I; Barni no. 67, pp. I2I-I23, Il. 34-42.
} 
Alciato never justified his behaviour with reference to his religious beliefs. It would therefore be problematic to characterize it as Erasmian. Erasmus's criticism of the emerging confessional dichotomy is driven by a theological agenda. Unlike Alciato, he constantly entered into debate to explain his position. Yet this attitude worried Alciato: Vehement debates with powerful clergymen could only cause problems. Most telling in this respect is his attempt to comfort Erasmus in 1530, when the humanist was demoralized by the constant attacks of his opponents. According to Alciato silence is now the best response, "otherwise what end will this business ever have?" 38 Thus, Alciato prefers a distinctly un-Erasmian reticence to the active promotion of religious reform within the tradition of the Catholic Church.

Alciato's case usefully illustrates the flexibility of religious language and the variety of motifs behind it. This can also be noticed in other emblematists. Sambucus, for example, privately sympathized with Lutheranism, but adapted his language for pragmatic reasons. He could complain about the "papist works" that his Antwerp printer Christopher Plantin engaged in (and which delayed his own publications), but also express his grief about the death of Pope Pius IV, and welcome his successor Pius V. ${ }^{39}$ In the end, he detested the confessional divisions mostly for obstructing scholarship: "Our religious disputes are so heated, that I would rather keep aloof for quite some time than hear and watch distressing, unfair things every day; the external sensitivities slow down my writing completely." 40

This adaptive behaviour has important implications for the interpretation of the religious language of the emblems. Especially the inclination to avoid religious controversy for pragmatic reasons undercuts the hypothesis that the emblems were meant to communicate a hidden, potentially controversial religious message. More evidence can be found when we turn from considering what the authors wanted to avoid, to what they aspired to achieve. A particularly important clue in this respect is the intended readership, for which the most explicit indicator is the dedication.

38) Alciato to Erasmus, 7 October 1530 , Barni no. 64, pp. II4-II8, quotation from 1l. 9093 (= Allen no. 2394, 11. 95-97). Later to Amerbach about his attempts "somehow to console" Erasmus, Alciato again expresses his hope that Erasmus would not immortalize his opponents in a new apologia to them. Alciato to Amerbach, 8 February I53I, Barni no. 67, I2I-I23, 11. 26-42, esp. 26-34.

39) He was, for example, reprimanded for having his children baptized by Lutheran ministers; Visser, Joannes Sambucus (see above, n. II), pp. 29-32, 55, I43-I44.

40) To Zwinger, Gerstinger, no. cxlii, pp. 250-25I, I4 May 1579. 


\section{Authors and Their Motives, 2: Managing Friendship}

One of the assets of the emblem book for the ambitious early modern author was its space for dedications. Not just collections as a whole could be dedicated to important patrons, but each individual emblem could be presented as a gift to specified "friends." Achille Bocchi was the first to dedicate a substantial number of single emblems, featuring many of the members of his academia in Bologna. The practice was soon followed by Sambucus, Junius, Reusner, and Taurellus. In each work, the dedications identify a select group of intended readers from whom the authors hoped to receive some form of support, or with whom they were keen to associate themselves. Read in this light, the same religious concepts (of personal spirituality and reservations about institutionalised religion) take on a range of different meanings, dependent on specific historical and local settings. In all the cases, however, the composition of network reveals that the authors accommodated a variety of religious positions among their readers.

This point has not been sufficiently taken into account in studies of Bocchi's emblems. His work has been associated with the cause of the spirituali, the evangelical circles around Cardinals Gasparo Contarini and Reginald Pole, who emphasized the importance of faith, advocated reform of ecclesiastical institutions and believed the church could still be reunited. ${ }^{41}$ Carlo Ginzburg went even further, seeing it as a subtle campaign for active simulation and concealment. ${ }^{42}$ Such claims were substantially based on Bocchi's dedications to spirituali. One of his Ganymede emblems, for example, is dedicated to Pole. Yet Bocchi also dedicates emblems to men of unsuspected orthodoxy, including the Bolognese inquisitor Reginaldo Nerlio, the conservative bishop (and historian) Paolo Giovio, as well as all popes of the last thirty years before publication. These dedicatees are unlikely recipients of either spirituale messages, or calls for dissimulation. Moreover, a heterodox strategy sits uneasily with Bocchi's immediate social position. For Bocchi was not just a private scholar working in the protected setting of his own academy, but a member of a patrician family in Bologna with civic responsibilities. He was commissioned, for example, to

\footnotetext{
41) Rolet, 'Achille Bocchi's Symbolicarum Quaestionum,' pp. I23-I28.

42) Ginzburg, Il nicodemismo (see above, n. 24), pp. I79-I8I, focuses in particular on Bocchi's symbol about Proteus, dedicated to the Calvinist Renée of France, Duchess of Ferrara; a careful evaluation by Watson, Achille Bocchi (see above, n. I4), pp. 23-50, concludes that there is insufficient evidence.
} 
write the history of Bologna, and acted as the teacher of the papal legate, Cardinal Ascanio Sforza. ${ }^{43}$

Instead, Bocchi's emblematic dedications can better be regarded as playful intellectual gifts, in which the constant use of paradox and ambiguity anticipated a shared taste for intellectual sophistication. Consider Bocchi's emblem to Nerlio, 'Adversus Iram' (Against anger [symbol I26], Plate 7). The pictura of this emblem represents the mocking of Christ. Similar in style to Hieronymus Bosch, Christ is here surrounded by seven caricature figures whose attributes suggest various heresies and signs of violence. ${ }^{44}$ The textual parts interpret these themes in moderate terms. Nerlio is first addressed as "the most upright defender of the innocent Lamb," followed by the statement: "It is the habit of the noxious to harm innocence." Robustly anti-heretical as these words may sound, the epigram takes a more equivocal stance. Here the moral correctness of anger is questioned, justifying only those cases where one's spiritual integrity is threatened. A final prayer to Christ asks for a clear judgment in the battle against those who harm innocence, and for the ability to love one's enemies. A modern reader may find it hard to associate the inquisitor's "defence" of Christ with "love," and be inclined to read in Bocchi's emblem criticism of inquisitorial practices. ${ }^{45}$ Yet to Nerlio it must have presented a perfectly acceptable form of support.

Similar strategies can be seen in later emblem collections. The networks in Sambucus, Junius, and Reusner - produced when confessional divisions had become increasingly fixed - were clearly supra-confessional. Sambucus's dedicatees, for example, present an international elite, including (apart from the Emperor for the collection as a whole) famous humanists from Italy, France,

\footnotetext{
43) Watson, Achille Bocchi (see above, n. I4), pp. 20-22, 5I-54.

44) The heretics include a Muslim and a Jew (on the left, his head partly covered by a prayer cloth). As yet unidentified are the three figures behind the cross with fanciful hats and amulets: could they represent Luther, Erasmus, and Melanchthon? Bonasone's engraving combines elements of Bosch's painting of Christ being crowned with thorns in the National Gallery, London (NG4744, see C. Baker and T. Henry, The National Gallery Complete Illustrated Catalogue (London, 1995), p. 54) and that of Christ bearing the cross, in the Museum voor Schone Kunsten in Gent.

45) E.g., according to Anne Rolet the epigram criticizes inquisitorial practices and the dedication should be seen as a formality. She reads Bocchi's concluding prayer as a wish to abolish the persecution of heretics and as support for the evangelical doctrine of justification through faith; Les symbolicae quaestiones d'Achille Bocchi (I555): recherche sur les modèles littéraires, philosophiques et spirituels d'un receuil d'emblèmes à l'époque de la Réforme (édition, traduction et étude d'ensemble) [unpublished doctoral thesis] (Tours, 1998), pp. I25I-I255.
} 


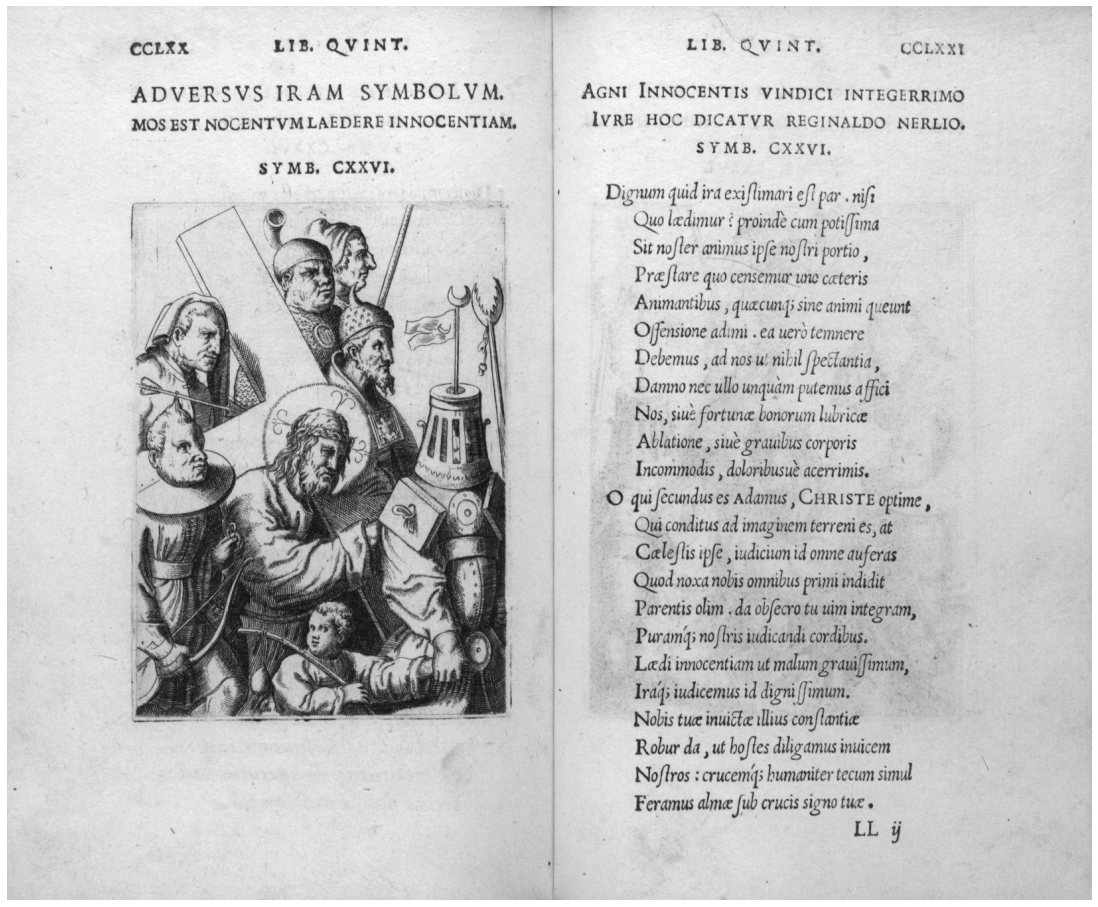

Plate 7. Giulio Bonasone's engraving to Bocchi’s 'Adversus Iram' (Against anger) depicts the mocking of Christ in the style of Hieronymus Bosch. The caricature figures of the torturers represent various heresies, such as a Muslim, in armor, on the right, and a Jew, with prayer-cloth, in the upper left corner. Photo: Glasgow University Library.

Germany, and the Low Countries, high-ranking dignitaries at the Habsburg court and ecclesiastical officials from his native Hungary. His intended readership reflects a spectrum of religious positions, including outspoken Catholics, Lutherans, and Calvinists: The conservative Hungarian archbishop Nicolaus Oláh could thus find himself in the company of the Reformed martyr Peter Ramus. Clearly, Sambucus did not select the dedicatees for their religious preferences, but rather for their social credit and potential patronage. Sambucus's book was published at the end of an extensive peregrinatio academica, just before his return to the Habsburg court. The dedications help to present the author as a well-connected member of the Republic of Letters, someone who could usefully serve the Emperor as a scholar and cultural agent. ${ }^{46}$

46) Visser, Joannes Sambucus (see above, n. II), pp. III-I3I. 
In cases like these, it is highly unlikely that the religious language was meant to convey anything else than a general, a-confessional message, accommodating the religious diversity of the intended readers.

A final example of how the dedication can reveal the author's motives is the case of Schoonhovius, where avoiding confessional language was part of a political strategy. Ostensibly, his book promotes neo-Stoic values inspired by the teachings of Justus Lipsius, such as steadfastness and the extirpation of emotions. ${ }^{47}$ Yet the dedication of his collection, to the magistrates of his hometown of Gouda, places the book at the heart of a political crisis in the Dutch Republic. On a theological level, the crisis resulted in the triumph of the strict Calvinists over the more liberal Arminians. In the late summer of I6I8 the regents who had supported the Arminians were arrested, and town councils purged. ${ }^{48}$

In his dedicatory letter, Schoonhovius shows his commitment to the policies of the liberal magistrates of Gouda. Moreover, he presents his Emblemata not just as a token of gratitude, but as political advice, part of a "fruitfully deceptive genre" of considerable philosophical importance. ${ }^{49}$ This turns Schoonhovius's plea for personal spirituality into a practical political strategy to avoid religious controversy and maintain some degree of unity in the Calvinist church. Moreover, the dedication highlights the author's personal involvement in this political agenda, as a member of a regent family. ${ }^{50}$ Ultimately, the book came too late to achieve the desired effect. Schoonhovius kept silent afterwards and

47) Jill Kraye, 'Moral Philosophy,' in The Cambridge History of Renaissance Philosophy, ed. Charles B. Schmitt and Quentin Skinner (Cambridge, 1988), pp. 370-374; in Schoonhovius, nos. 2 'Sapiens supra fortunam' (The wise man is above fortune); 5 'Nihil ignavis votis' (Nothing happens by cowardly prayers); 23 'Sapiens quo foelicior, eo modestior' (The happier the wise man is, the more modest); 25 'Rationis cum affectibus bellum' (Reason's war with emotions); and 4I 'Sapiens supervacanea bona negligit' (The wise man ignores pointless prosperity).

48) Jonathan I. Israel, The Dutch Republic: Its Rise, Greatness and Fall I477-I806 (Oxford, 1995), pp. 393-394, 42I-432; A.Th. van Deursen, Bavianen en Slijkgeuzen: kerk en kerkvolk ten tijde van Maurits en Oldebarnevelt (Assen, 1973).

49) Schoonhovius, sig. ${ }^{*} 2^{\text {ro }-*} 4^{\text {vo }}$.

50) Ibid., sig. ${ }^{*} 3^{\text {ro }} *^{*} 3^{\text {vo }}$. Schoonhovius's father Dirk Jacobsz. was a member of the city council (vroetschap) from 1599 to June I6I7, serving as burgomaster in I6II, I6I2, I6I5, and I6I6; he was one of deputees at the States General from May/July I6I7 to April I6I8 and from June to November of I6I8, see J.G. Smit, Resolutiën der Staten Generaal. Nieuwe Reeks I6I0-I670. Part 3, I6I7-I6I8. [Rijksgeschiedkundige Publicatiën I52] (The Hague, I975), s.v. 'Schoonhoven, Dirk Jacobsz.' Schoonhovius grandfather from his mother's side was burgomaster in 1576, see Ignatius Walvis, Beschrijving der stad Gouda (Gouda: J. and 
there is evidence that he converted to Catholicism. ${ }^{51}$ By I6I8, it seems, an a-confessional language had become virtually impossible.

Thus, the dedications too invalidate the idea of a concealed religious message, revealing instead how social and political aspirations stimulated a religious language that accommodated different positions. In this way the authors tried to ensure a favourable reception from the readers they had in mind. What they could not control, however, was their subsequent wider readership. How, then, did the thousands of individual buyers understand the confessional silence in these learned emblem books? What did they think of Ganymede, Cecrops, Polyphemus, and Hermes Trismegistus?

\section{How Individual Readers Used Their Emblems}

Although the reception of emblem books by individual readers is still largely unexplored and the evidence too fragmentary to allow for a comprehensive synthesis here, two factors indicate that they were not regarded as heterodox literature. ${ }^{52}$ First, the sheer numbers of production suggest that the books were regarded as safe entertainment. As indicated before, Alciato forms a class apart, with over a hundred editions before 1620. Yet generally the emblem books discussed here were reprinted several times: Sambucus appeared in six Latin editions (as well one in Dutch and one in French), Junius in seven (as well as three editions in French and two in Dutch), Taurellus in two, and Schoonhovius in four. The elitist, hermetic symbols of Bocchi also kept their appeal in the Counter-Reformation, with a new edition being issued in 1574. There are no solid data to calculate precise production numbers for all of these works, but an estimate of one thousand copies for each edition

A. Endenburg/Leiden: C. Vermey, I7I4), pp. 87-88; Nationaal Archief, The Hague, Hof van Holland, I428-I8II, part 3624, electies van burgemeesters en schepenen, file Gouda.

51) Walvis, Beschrijving (see above, n. 50), p. 313; Xander van Eck relates an incident in I638, where Schoonhovius seems to have hosted a Catholic house service, see his Kunst, twist en devotie: Goudse katholieke schuilkerken I572-I795 (Gouda, I994), p. I27.

52) For studies of readers of emblems, see Jochen Becker, 'Geistlich oder geistreich: vom Sinn "emblematischer" Bilder,' in Die Domänen des Emblems: Ausserliterarische Anwendungen der Emblematik, ed. Gerhard F. Strasser and Mara R. Wade (Wiesbaden, 2004), pp. 233-26I; Arie Jan Gelderblom, 'Who were Jan Luyken's Readers?' in Dekoninck and GuiderdoniBruslé, Emblemata sacra (see above, n. 9), pp. 499-507. Seminal studies of the transformative role of the reader are Carlo Ginzburg, The Cheese and the Worms: The Cosmos of a Sixteenth Century Miller (Baltimore, 1992); Anthony Grafton and Lisa Jardine, " "Studied for Action": How Gabriel Harvey Read His Livy,' Past and Present I29 (I990), 30-78. 
is reasonable, which gives a rough indication of the magnificent scale on which these books were produced. The Frankfurt book fairs guaranteed the dissemination of these works all over Europe..$^{53}$ Alciato's emblem book, for example, was owned by Catholic priests and Calvinist ministers alike, ranging from Italy to the Low Countries. ${ }^{54}$ Together, the large-scale production and international distribution powerfully illustrate the supra-confessional market of these books.

Second, neither Protestant nor Catholic authorities expressed objections against the humanist emblem. The only work that briefly featured on the Spanish Index of Forbidden Books (1584) was Junius's Emblemata, but this was a result of a general ban on his works, caused by controversial remarks in his Greek dictionary. ${ }^{55}$ Individual users could, however, appropriate the emblems in a confessional way. An interesting example is the sixteenth-century French poet Simon Bouquet, who left a manuscript with adapted translations of Alciato's emblems (c. 1590). Here the image of the Whore of Babylon (in 'Ficta religio,' discussed above) becomes a symbol of the Reformed churches:

53) For print runs of emblem books published by the Plantin press, see Visser, Joannes Sambucus (see above, n. II), pp. 69-77; for dissemination, see Stephen Rawles's census of emblem books in the catalogues of the Frankfurt and Leipzig book fairs: http://www.emblems.arts. gla.ac.uk/Book_Fair_Catalogues.html.

54) Thomas B. Deutscher, 'From Cicero to Tasso: Humanism and the Education of the Novarese Parish Clergy (1565-1663),' Renaissance Quarterly 55 (2002), 1005-1027, there IO2I; Willem Frijhoff, 'Vier Hollandse priesterbibliotheken uit de zeventiende eeuw,' Ons Geestelijk Erf 51 (1977), 198-302, there 227 and 233; The Auction Catalogue of the Library of J. Arminius, ed. C.O. Bangs (Utrecht, 1985), p. 36. The only emblem that caused offence was 'Adversus naturam peccantes' (Those sinning against nature); see William S. Heckscher, 'Pearls from a Dung-Heap: Andrea Alciati's "Offensive" Emblem: Adversus Naturam Peccantes,' in Art the Ape of Nature: Studies in Honor of H.W. Janson, ed. Moshe Barasch and Lucy Freeman Sandler (New York, 198I), pp. 29I-3II. Yet it was not listed on the Index (pace Heckscher at pp. 29I-293). More sensitive was Alciato's work on duelling, a forbidden topic since the Tridentine index (I564); see Claudio Donati, 'A Project of "Expurgation" by the Congregation of the Index: Treatises on Duelling,' in Church, Censorship and Culture in Early Modern Italy, ed. Gigliola Fragnito (Cambridge, 200I), pp. $134-\mathrm{I} 62$.

55) Index de l'Inquisition Espagnole 1583, 1584, Index des livres interdits VI, ed. J.M. de Bujanda et al. (Sherbrooke, I993), pp. 823-824. Junius had been banned on the Roman index of 1564 , because "he clearly showed himself to be a Lutheran" in his definition of "pistis" in his Greek-Latin dictionary; see Index de Rome 1557, I559, I564, Index des livres interdits VIII, ed. J.M. de Bujanda et al. (Sherbrooke, I990), p. 488. 
Religion feinte

Celle la que tu vois superbement assize

Sur un trosne royal, cette belle putain

Qui monstre a découuert son impudique sein

Dont Geneue se voit éperdument éprize

Qui prenant faucement le manteau de leglize

De pourpre se repare, et qui tenant en main

Le calice sacré rend le troupeau germain

Yure de la poyson que peu cault il a prize:

Celle qui par lattraict du beau va deceuant

Le trop credule esprit de langloys peu scauant

Qui est en ce tableau si naiuement peinte

Celle qui a longs traictz feit humer son venin

A huz, prague, vinclef A luther et Caluin

Se nomme refformée ou religion feinte. ${ }^{56}$

Bouquet's adaptation shows that Alciato's emblems need not be associated with anti-Catholic criticism, in the tradition of the evangelical propaganda against the pope, but could even serve the opposite cause.

Finally, the use of emblem books as alba amicorum confirms this neutral status. ${ }^{57}$ This practice of collecting personal inscriptions of friends and influential connections became popular among German students in the middle of the sixteenth century and quickly spread over Europe. Emblem books take a special place in this genre. Out of 310 printed books catalogued in the repertory of sixteenth-century alba, more than a third (III) are copies of Alciato. Sambucus (23), Junius (19), and Reusner (13) feature heavily as well. ${ }^{58}$ Since

56) Simon Bouquet, Imitations et traductions de Cent dixhuict emblesmes dAlciat (Bibliothèque Nationale de France, ms. fr. I9.I43), ed. Daniel Russell and Catharine Randall (New York, 1996), pp. 147-I48. Another example is 'In adulari nescientem' (pp. 136-I37), adapted to address the politico-religious troubles in Flanders.

57) Carsten-Peter Warncke, 'Über emblematische Stammbücher', in Stammbücher als kulturhistorische Quellen, ed. Jörg-Ulrich Fechner (Munich, 198I), pp. 197-226; Victoria Musvik, 'Word and Image: Alciato's Emblemata as Dietrich Georg von Brandt's Album amicorum,' Emblematica I2 (2002), I4I-I63; Walther Ludwig, Das Stammbuch als Bestandteil humanistischer Kultur: Das Album des Heinrich Carlhack Hermeling (1587-I592) (Göttingen, 2006); about alba amicorum in general, see Wolfgang Klose, Corpus alborum amicorum: Beschreibendes Verzeichnis der Stammbücher des 16. Jahrhunderts (Stuttgart, 1988); W.W. Schnabel, Das Stammbuch. Konstitution und Geschichte einer textsortenbezogenen Sammelform bis ins erste drittel des I8. Jahrhunderts (Tübingen, 2003) and Stammbücher des I6. Jahrhunderts, ed. Wolfgang Klose (Wiesbaden, 1989).

58) Klose, Corpus alborum amicorum (see above, n. 57), p. 364 (overview of totals; for Reusner 
the alba typically document the academic tours of individual students through Europe, they offer interesting evidence of how the emblem helped members of the Republic of Letters to bridge confessional divides.

First, the emblems allowed the users of these alba generous interpretational freedom. Indeed, it is striking to notice that there often seems to be no close relation between the message of the emblem and the entry. In the album of the German student and nobleman Heinrich Carlhack Hermeling (I57I-I6I4), for instance, only six out of 93 entries comment on one of Paradin's emblems. ${ }^{59}$ Similarly, in the Alciato copy of Leo Roelofs from Antwerp only a very general association seems to connect the entry of Constance de Lougenhage to an emblem about the brevity of happiness: Her short poem in French wishes her friend "health, a good life, fine horses, a pretty girlfriend, gold, silver, and paradise after death." ${ }^{60}$ In fact, the place of an entry is more often determined by the social status of the contributor (nobility and authorities should come first) than by the contents of the book. ${ }^{61}$

Semantic flexibility and confessional silence made the books ideal for interconfessional contacts. Significantly, the entries resulting from such contacts adopt the same a-confessional language as the emblems themselves. A case in point is again the Lutheran student Hermeling, who on his academic tour through Lutheran, Calvinist, and Catholic areas usually met representatives of the church as well. ${ }^{62}$ In Catholic Ingolstadt he invited Hubertus Giphanius to add an inscription. This professor of philosophy had recently converted to Catholicism, which had been celebrated publicly in Ingolstadt. Yet his entry

his portrait collections are excluded here); the total number of alba amicorum described exceeds I,535 (p. vii); most of these are manuscript compilations.

59) Ludwig, Das Stammbuch (see above, n. 57), p. 89, note 46; in 3 other cases an entry could have referred to an existing emblem, but fails to do so. For the different degrees of correspondence, see Warncke, 'Über emblematische Stammbücher' (see above, n. 57), and Musvik, 'Word and Image' (see above, n. 57), esp. p. 159.

60) "Dieu vous donne sante et bonne vie / de beaus cheuals et de belle amie / Or et argent quant tu vouldras / le paradies quant tu mouras." Album amicorum of Leo Roelofs, Royal library, The Hague, sig. $74 \mathrm{H}$ 20, entry on page facing p. 136 ('In momentaneam felicitatem'; 'On short-lived happiness'), dated I58I.

61) Alba amicorum: vijf eeuwen vriendschap op papier gezet: het album amicorum en het poëziealbum in de Nederlanden, ed. K. Thomassen (Maarssen, I990), pp. I6-I9.

62) Ludwig, Das Stammbuch (see above, n. 57), p. 59: in Helmstedt he met the radical Lutheran Tilemann Heshusius, in Bremen the Calvinist Christoph Pezel, in Basel the antistes of the Basel Reformed church and theology professor Johann Jakob Grynaeus and in Geneva Théodore de Bèze and David Le Boiteux, and in Ingolstadt probably the Catholic theologian Matthias Beegius. 
to Hermeling (d.d. 5 April 1592), dealing with religion, is deliberately accommodating: "No sane person is against reason, no Christian against faith, no peaceful man against the Church.” In I600, the Puritan theologian William Perkins could similarly edify the Dutch student Daniel Burgravius in confessionally neutral terms: "Let the love of God and the Church overcome all other desires." So long as they kept silent about which church they spoke, both professors shared the same ideals. ${ }^{63}$

\section{Conclusion}

The scholarly community was, of course, only in theory a Republic. It was not governed by written rules such as those of publisher Christopher Plantin, who simply forbade his employees "to engage in disputation either in opposing or defending any matter concerning religion." 64 Explicit rules like these helped Plantin to be a successful publisher of learned works, catering both to confessional and non-confessional markets, including many collections of emblems. The case of the emblem book suggests how a similar, unwritten code of confessional silence helped the members of the sixteenth-century scholarly community to negotiate religious diversity, and maintain communication.

This strategy reveals another side of the dynamic relationship between humanism and confessionalization. Apart from employing humanists to implement religious reform, confessionalization also induced the intellectual elite to retreat to an alternative religious language, based on the shared heritage of the classics. In emblem books humanists used this common cultural framework to articulate a remarkably coherent response, emphasizing the

63) Ludwig, Das Stammbuch (see above, n. 57), pp. I06-107, no. 8: "Contra rationem nemo sobrius, / Contra fidem nemo Christianus, / Contra Ecclesiam nemo pacificus sentit." [fol. $44^{\mathrm{vo}}$, facing p. 79]; based on Augustine, De trinitate 4.6, where "scripturam" (Scripture) instead of "fidem" (faith); about Hermeling's stay in Ingolstadt, see ibid., 5254. I disagree with Ludwig's interpretation of the inscription as a form "propaganda for the Roman Catholic church" (p. 8I), since the nature of church is not specified. Ludwig himself (p. I08) illustrates that the inscription is amenable for interconfessional use when mentioning that the evangelical minister Georg Horn used the same text for an album inscription in 1602; Horn significantly added that "No sensible man is against conscience" ("Contra conscientiam nemo probus"). For Perkins's entry, see Daniel Burgrave's album, a

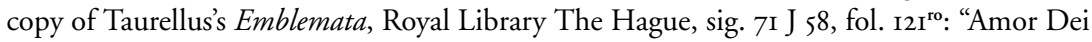
et Ecclesia vincat caeteros affectus."

64) Quoted from the 1563 ordinance by Leon Voet, The Golden Compasses: A History and Evaluation of the Printing and Publishing Activities of the Officina Plantiniana at Antwerp, 2 vols. (Amsterdam, 1969-1972), 2: 358. 
personal nature of spirituality and expressing reservations against institutional forms of religion. Yet behind the unchanging rhetoric diverse purposes can be distinguished, determined by specific social and political contexts. What they shared was a wish to communicate with people of diverse religious sympathies.

This highly stylised, neutral language made the humanist emblem a safe form of entertainment for a diverse humanist readership. The prominence of these emblem books among alba amicorum shows that they were particularly effective in facilitating social interaction beyond the religious divides in the second half of the sixteenth century, such as for students on an academic tour. The semantic flexibility and confessional neutrality of the books provided owner and contributor ample opportunity to find common ground. In this way too the silence of these speaking pictures helped to maintain communication in the humanist community. After the first quarter of the seventeenth century, this strategy became increasingly rare. Conversely, many new collections from this period conveyed an outspoken confessional message for pedagogical or devotional purposes.

A final point concerns the form of evidence. Although it is perhaps easier to discern confirmations, rejections, or calls for moderation, other responses to confessional discipline can still be described. More sensitivity for implicit signals, such as confessional silence, and stylised sources, such as Latin poetry, could help scholars come to a better understanding of those who tried to escape discipline, avoid conflict and resort to a language in which confessional distinctions did not exist.

Dr. Arnoud Visser, University of St Andrews, School of Classics, Swallowgate, Butts Wynd, UK - St Andrews, Fife KYı 9AL; asqv@st-and.ac.uk 